\title{
Atopy in cutaneous and arthropatic psoriasis
}

\author{
E Hajdarbegovic $^{1 *}$, AAA Westgeest ${ }^{2}, H$ B Thio $^{1}$ \\ From 5th European Workshop on Immune-Mediated Inflammatory Diseases \\ Sitges-Barcelona, Spain. 1-3 December 2010
}

\section{Introduction}

Psoriasis is a chronic inflammatory disease where keratinocytes are stimulated to hyperplasia by immunocytes organised in a Th17/Th1-type (T- helper cell) dominated response $[1,2]$. In about $15 \%$ of the patients with psoriasis, arthritis will develop [3,4]. There have been studies which demonstrated antagonism between atopy and mainly Th-1 driven inflammatory and autoimmune diseases such as rheumatoid arthritis in which the presence of atopy confers a milder course of the disease [5].

Serum IgE levels have been investigated in psoriatic patients in the past. Nevertheless, there is little account for clinical correlation and no patients with psoriatic arthritis have been included in these investigations. Previous studies have found increased total levels of IgE together with increased sensibilization for specific inhalation allergens and even increased prevalence of atopic diseases [6-10].

\section{Aim}

The aim of this paper is to describe clinical and serological atopic manifestations in patients with psoriatic arthritis in more detail and compare this to patients with cutaneous psoriasis and a control group.

\section{Patients and methods}

One hundred and fifty outpatients with psoriatic arthritis (PSA), 150 patients with cutaneous psoriasis without arthritis (PSO), and a control group (CO) consisting of 150 patients with varicosities of the legs where included. Patients filled in a questionnaire on clinical atopic manifestations and blood was drawn for total IgE and specific inhalant IgE (Phadia AB, Sweden) determination.

\section{Results}

The prevalence of patient reported asthma was $8 \%, 15 \%$ and $20 \%$ in PSA, PSO and CO groups respectively. For

${ }^{1}$ Dept. of Dermatology, Erasmus Medical Centre, Rotterdam, The Netherlands Full list of author information is available at the end of the article hay fever we found prevalences of $9 \%, 14 \%$ and $19 \%$. The percentages of patients currently using inhalators were: $3 \%, 5 \%$ and $12 \%$. These differences were only significant for PSA vs. CO (chi square $\mathrm{p}<0,05$ ).

The percentages of patients with total IgE level $>100$ $\mathrm{kU} / \mathrm{L}$ was significantly lower in the PSA group compared to the PSO and CO group. (13\% vs. $31 \%$ vs. $23 \%$ $\mathrm{p}=0.022$ ).

Also the percentage of patients with increased level of inhalant allergen specific IgE $>0,35 \mathrm{phadia} / \mathrm{L}$ was lower in the PSA group ( $20 \%$ vs. $37 \%$ vs. $36 \% \mathrm{p}=0,006)$.

\section{Conclusions}

Patients with psoriatic arthritis have lower prevalences of clinical manifestations of atopy as well as of its serological markers when compared to patients with cutaneous psoriasis or non-psoriatic patients.

\section{Author details}

${ }^{1}$ Dept. of Dermatology, Erasmus Medical Centre, Rotterdam, The Netherlands. 2Dept. of Rheumatology, Maxima Medisch Centrum, Eindhoven, The Netherlands.

Published: 25 November 2010

\section{References}

1. Nograles KE, Brasington RD, Bowcock AM: New insights into the pathogenesis and genetics of psoriatic arthritis. Nat Clin Pract Rheumatol 2009, 5(2):83-91.

2. Di Cesare A, Di Meglio P, Nestle FO: The IL-23/Th17 axis in the immunopathogenesis of psoriasis. J Invest Dermatol 2009, 129(6):1339-50.

3. Ibrahim G, Waxman R, Helliwell PS: The prevalence of psoriatic arthritis in people with psoriasis. Arthritis Rheum 2009, 61(10):1373-8.

4. van Romunde LK, et al: Psoriasis and arthritis. I. A population study. Rheumatol Int 1984, 4(2):55-60.

5. Rabin RL, Levinson Al: The nexus between atopic disease and autoimmunity: a review of the epidemiological and mechanistic literature. Clin Exp Immunol 2008, 153(1):19-30.

6. Chen $Z Y$, et al: Immunoglobulin $E$ in psoriasis evaluated by paper radioimmunosorbent and paper enzyme-immunosorbent tests. Acta Derm Venereol 1985, 65(1):14-8.

7. Pigatto PD: Atopy and contact sensitization in psoriasis. Acta Derm Venereol Suppl (Stockh) 2000, , 211: 19-20.

8. Welp K, et al: [Concomitant psoriasis vulgaris and atopic dermatitis. A study of 1,065 patients with psoriasis] Koinzidenz von Psoriasis 
vulgaris und atopischer Dermatitis. Eine Untersuchung an 1,065

Psoriasis-Patienten. Hautarzt 1989, 40(8):496-500.

9. Ovcina-Kurtovic N, Kasumagic-Halilovic E: Serum levels of total

immunoglobulin $\mathrm{E}$ in patients with psoriasis : relationship with clinical type of disease. Med Arh 2010, 64(1):28-9.

10. Negosanti M, et al: IgE serum levels in psoriasis. Dermatologica 1981, 163(6):474-5.

doi:10.1186/1479-5876-8-S1-P15

Cite this article as: Hajdarbegovic et al:: Atopy in cutaneous and arthropatic psoriasis. Journal of Translational Medicine 2010 8(Suppl 1):P15.

Submit your next manuscript to BioMed Central and take full advantage of:

- Convenient online submission

- Thorough peer review

- No space constraints or color figure charges

- Immediate publication on acceptance

- Inclusion in PubMed, CAS, Scopus and Google Scholar

- Research which is freely available for redistribution

Submit your manuscript at www.biomedcentral.com/submit
C Biomed Central 